下腿内旋位でのレッグプレス運動が若年健常女性の歩行時足圧中心軌跡 および膝関節回旋可動域に及ぼす効果

\title{
The effects of a leg press exercise with tibial internal rotation on plantar pressure distribution during gait and knee rotational range of motion in healthy young females
}

\author{
蒲田 和芳 ${ }^{1)}$ 外間 源亮 ${ }^{2}$ 三田 和広 ${ }^{31}$ \\ 生田 太 ${ }^{1)}$ 米田 佳 ${ }^{4)}$ \\ Kazuyoshi Gamada1)， Gensuke Hokama²， Kazuhiro Mita ${ }^{3)}$ \\ Futoshi IkUTA ${ }^{1)}$, KeI Yoneta ${ }^{4}$
}

\begin{abstract}
要旨：変形性膝関節症（膝 OA）では下腿が外旋位にあり，下腿内旋位でのエクササイズ は即時的に膝 OAにおける膝内反アライメント, 膝関節屈曲および伸展可動域, 歩行時 痛を改善したと報告された。この効果発現のメカニズムの検証を進める上で, 膝OA と 健常膝の類似点と相違点を明らかにする必要がある。本研究では, 下腿内旋位でのレッグ プレス運動が，若年健常女性の歩行時足圧中心（COP）軌跡および下腿回旋可動域に及 ぼす効果を解明することを目的とした。健常女性20名20膝を, 無作為に下腿内旋エク开开 イズ群と下腿外旋エクササイズ群に割り付けた。それぞれ，下腿内旋位または外旋位での レッグプレス運動を 2 週間実施した。介入前後に下腿回旋可動域, 歩行時 COP 測定し た。下腿内旋エクササイズ群では下腿内旋可動域が拡大し, 歩行立脚後期におけるCOP は内側へ偏位した。下腿内旋位でのレッグプレス運動は，若年女性の健常膝において下腿 内旋可動域拡大と歩行中の COP 内側偏位をもたらす可能性が示唆された。今後, 膝 OA を対象とした同様の研究を実施する。
\end{abstract}

キーワード：健常者, レッグプレス, 足底圧分布, 下腿回旋可動域

\begin{abstract}
The osteoarthritic $(\mathrm{OA})$ knee demonstrated reduced tibial internal rotation during squat (Saari 2005) and a knee exercise with tibial internal rotation was effective on immediately improving symptoms (Yoshida 2013). A comparison between OA and healthy knees is necessary to determine the mechanism of the reason of the clinical effects. The aim of this study was to determine if a leg press exercise with tibial internal rotation is effective on plantar pressure distribution during gait and knee rotational range of motion in healthy females. Twenty healthy, young females were randomly allocated to internal or external rotation groups, who performed a leg press exercise with either tibial internal or external rotation, respectively, for two weeks. Knee rotational range and plantar pressure distribution during gait were measured. The internal rotation group demonstrated increased internal rotation and total rotation ranges as well as medial shift of the center of plantar pressure during gait. To conclude, the leg press exercise with tibial internal rotation induced a kinematic chain of combined tibial internal rotation and hindfoot pronation during gait. Future studies will include a similar study for patients with knee OA.
\end{abstract}

Key words: healthy subject, leg press, plantar pressure distribution, lower leg rotational range

受付日：2012年12月26日, 採択日：2013年 2 月27日

広島国際大学大学院 医療・福祉科学研究科

Graduate School of Medical Technology and Health Welfare Sciences, Hiroshima International University

干739-2695 東広島市黒瀬学園台555-36 広島国際大学 1 号館705号室

TEL0823-70-4550 FAX0823-70-4550 E-mail: kazgamada@ortho-pt.com

Hiroshima International University, 555-36 Kurose Gakuendai, Bldg 1, Rm 705. Higashi Hiroshima, Hiroshima, $739-2695$

2) 京都回生病院 リハビリテーション科

Department of Rehabilitation, Kyoto Kaisei Hospital

3) 山口リハビリテーション病院 リハビリテーション科

Department of Rehabilitation, Yamaguchi Rehabilitation Hospital

4) 小林病院 リハビリテーション科

Department of Rehabilitation, Kobayashi Hospital 


\section{I . 背 景}

変形性膝関節症（膝 OA）は，世界中で存在率の高 い慢性疾患である。日本に扔ける有病者数は，症侯性 の膝 OA を有する患者が約 780 万人，無症候性を含め ると約 2,530 万人と推定された ${ }^{1)}$ 。世界に先駆けて超高 齢社会を迎えた本邦は, 今後も膝 OA が増加してい くと予測される。膝 OA に対する再現性の高い治療 法として高位脛骨骨切術や人工関節置換術があるが, 末期膝 OA に対する人工膝関節置換術は平均 2 万 700 ドルの費用が必要であると報告された2)。これら観血 的治療法の増加は, 社会的・経済的に大きな負担とな ることは避けられない。したがって, 膝 OAの予防 法の確立は医療経済上においても重要な課題であり, 予防介入は退行性変化の小さい発症前から行われるこ とが好ましいと考えられる。

膝 OA の大部分は内反変形を特徵とする内側型膝 OA である。Framingham studyによると，内側型膝 OA の有病率は外側型膝 OA と比較し, 女性で5. 1倍, 男性で7.8倍とされた 対象としたバイオメカニクス研究が報告され, 膝 OA の発症や進行の危険因子について議論が続いている。 内側型膝 OA のスクワット動作に掞ける膝関節キネ マティクス解析では, 全屈曲運動域において大腿骨に 対して脛骨が外旋していたと報告された ${ }^{4,5)}$ 。これに対 して, 吉田 $ら^{6)}$ は, 内側型膝 $\mathrm{OA}$ 患者を対象に下腿内 旋位でのレッグプレス運動を 4 週間実施した結果，立 位時の大腿骨内側顆間距離や Q-angle の減少，膝関節 屈曲および伸展可動域や歩行時痛, $10 \mathrm{~m}$ 歩行歩数の減 少などの効果が認められたと報告した。また，健常群 と膝 OA 群の足底圧中心 (COP) を計測した研究で は, 歩行初期接地から立脚中期の COP は膝 OA 群に おいて外側に偏位していたと結論づけられた7)。膝 OA における踵接地から開始される COP の外側偏位には 後足部の内部回外モーメントの関与が強く示唆され, 下腿内旋エクササイズによる下腿外旋と後足部の内部 回外モーメントの減少を促す運動療法が膝 OA に有 効であることが示唆される。しかしながら，下腿内旋 位でのレッグプレス運動の治療効果のメカニズムは未 解明であり，健常膝や膝 OA において上記の運動連 鎖の変化が実際に起こることは実証されていない。本 研究では, 若年健常女性の健常膝を対象に, 下腿内旋 位でのレッグプレス運動が歩行時足圧中心 $(\mathrm{COP})$ 軌跡および膝関節回旋可動域に及ぼす効果を解明する ことを目的とした。本研究の仮説は,「下腿内旋位レッ
グプレス運動は下腿内旋可動域拡大と歩行時 $\mathrm{COP}$ の 内側偏位をもたらす」とした。

\section{II. 方 法}

\section{1. 対 象}

対象の包含基準は，18-30歳の健常女性であり，除 外基準は下肢に外傷の既往がある者，歩行時に疼痛を 有する者, 精神病患者, コミュニケーションに障害の ある者, 研究内容の理解に問題のある者とした。以上 の基準を満たした女性20名の右下肢20膝を対象とし， 内旋運動群と外旋運動群に無作為かつ均等に割り付け た。本研究は広島国際大学保健医療学部倫理小委員会 の承認を得て，対象者への身体的・精神的苦痛㧍よび 情報漏洩の防止に配慮して実施された。全ての対象者 はあらかじめ研究内容に関する説明を受け，ヘルシン キ宣言の精神に基づき作成された参加同意書に署名し た後に研究に参加した。

無作為割り付けは，介入と測定のいずれにも関与し ない研究者が実施した。Microsoft Excel 2010のラン ダム関数によって生成された乱数の一覧表に，同意書 に署名した順に対象者を割り当て, 乱数の小数点以下 2 椼の偶数·奇数により 2 群に割り付けた。検者は, 無 作為割り付けの結果を知らず，対象者が実施した介入 内容について知識のない状態ですべての介入を実施し た。統計学的検定を実施する直前に盲検化を解除した。

\section{2. 方 法}

本研究は, 下腿内旋エクササイズ群と下腿外旋エク ササイズ群の 2 群に分けた盲検・無作為化対照研究

(RCT) である。介入期間は 2 週間であり，その前 後に下腿回旋可動域㧍よび歩行時 COP 軌跡の測定を 実施した。

下腿回旋可動域の測定には，自作の下腿回旋可動域 測定装置（図 1) を使用した。この装置は，足関節固 定用ブーツ（Aircast 社）と回転盤から構成される。 ブーツ内に設置されたair cell 内に空気を注入するこ とにより，ブーツと足部・下腿を密着させた。ブーツ の足底面と回転盤とを密着するよう成型された合成樹 脂を回転盤上に設置した。測定肢位は，遠位大腿部を 固定した椅子座位で，股関節および膝関節 $90^{\circ}$ 屈曲位 とした。介入前後における安静時回旋角度と自動内旋 および自動外旋角度を計測した。また，本装置を用い た測定方法の信頼性を検証するため，以下の介入を実 施する前に，1日5 回の測定を 2 日以上の間隔をあけ 


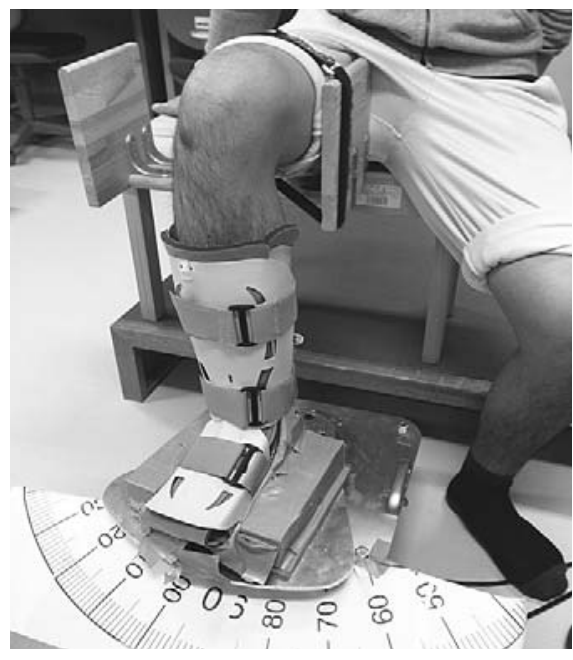

図 1 簡易的下腿回旋可動域測定装置

\section{て 2 回実施した。}

歩行時 COP は, pedar-X 足圧分布測定装置 (novel 社）を用いてトレッドミル歩行を計測した。COPが 安定した10歩のデータの平均值を解析に使用した。足 部のランドマークとして，1）母趾中足趾節（MP） 関節，2）舟状骨結節，3）母趾 MP 関節および舟 状骨結節の中点，4）踵部，の4 点を床上においた紙 上でマーキングし，パソコン画面上に表出される圧分 布画像に反映させた。上記の各ランドマークを通る横 軸に対する COP との交点を算出し, 介入前後におけ る COP の側方偏位率（\%）を求めた。

介入にはリアライン・レッグプレス (GLAB 社製)

（図 2 ）を用い，椅子座位にて下腿内旋または外旋位 におけるレッグプレス運動を実施した。下腿内旋エク ササイズ群は，1）膝屈曲 $90^{\circ}$ 屈曲位での下腿内旋の 反復, 2) 内側ハムストリングスの十分な緊張を保ち ながらの下腿内旋位でのレッグプレス運動の反復, を 実施した。下腿外旋エクササイズ群は，1) 膝屈曲 $90^{\circ}$ 屈曲位での下腿外旋の反復, 2) 下腿外旋位でのレッ

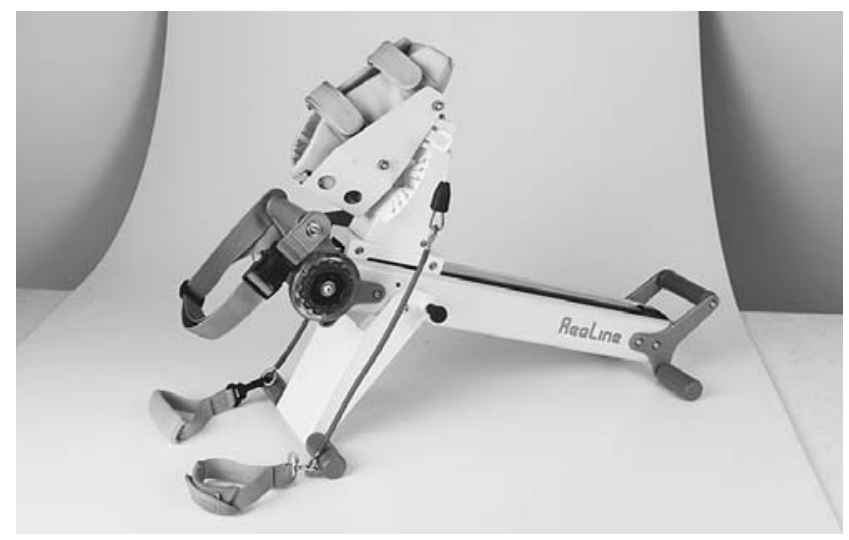

図 2 リアライン・レッグプレス (GLAB 社)
グプレスの反復，を実施した。それぞれ 1 セット 30 回 とし， 2 週間で合計10セット行った。レッグプレスの 抵抗は約 $9 \mathrm{~kg}$ であった。

簡易的下腿回旋可動域測定装置のテス卜間および日 間の信頼性の検討には, 級内相関係数（ICC）を使用 し，さらに日間の測定值の標準誤差（SEM）を算出 した。二群間の身長および体重の比較には 2 標本 $\mathrm{t}$ 検 定を使用した。下腿内旋エクササイズ群および下腿外 旋エクササイズ群の介入前後での群内および群間比較 には反復測定二元配置分散分析を使用し，Post-hoc 検 定には Bonferroni 補正法を用いて p 值を補正した上 で， 2 標本 $\mathrm{t}$ 検定を用いた。Bonferroni 補正後の有意 水準 0.0125 （補正前；0.05）未満を統計学的有意とみ なした。統計ソフトはPASW Statistics 18 (SPSS Japan）を使用した。

\section{III. 結 果}

\section{1. 簡易的下腿回旋可動域測定装置の信頼性}

テスト間の ICC $(1,1)$ は安静時回旋角度0.97, 自動内旋角度 0.79 , 自動外旋角度 0.86 であり, 日間の 信頼性 ICC (1，5）拈よびSEM は安静時回旋角度 $0.62\left(0.71^{\circ}\right)$, 自動内旋角度 $0.86\left(1.22^{\circ}\right)$, 自動外旋 角度 $0.67\left(1.02^{\circ}\right)$ であった。

\section{2. 対象者属性}

下腿内旋エクササイズ群の身長は $157.3 \pm 4.7 \mathrm{~cm}$ (平 均值士標準偏差), 体重は50.6 $06.1 \mathrm{~kg}$ であり, 下腿外 旋エクササイズ群の身長は159.2 $26.9 \mathrm{~cm}$ ，体重は54.0 $\pm 7.9 \mathrm{~kg}$ であった。身長および体重に二群間に統計学 的有意差は認められなかった。また，全対象者が所定 の介入をすべて実施した。

\section{3. 下腿回旋可動域}

いずれの項目においても介入前の群間差および交互 作用は検出されなかった。下腿内旋エクササイズ群の 介入前の安静時回旋角度は外旋 $2.7 \pm 3.4^{\circ}$, 自動内旋 角度は $24.1 \pm 5.9^{\circ}$ ，自動外旋角度は $32.7 \pm 6.3^{\circ}$ であり， 下腿外旋エクササイズ群の介入前の安静時回旋角度は 外旋 $3.5 \pm 1.8^{\circ}$, 自動内旋角度は $32.7 \pm 7.1^{\circ}$, 自動外 旋角度は38. $0 \pm 5.7^{\circ}$ であった（表 1 )。下腿内旋エク ササイズ群では介入により自動内旋角度が $11.9 \pm$ 10. $4^{\circ}$ 増加したのに対し $(\mathrm{p}=0.024)$, 下腿外旋エク ササイズ群では介入前後で有意差は認めなかった（表 1 )。 
表 1 下腿回旋可動域の変化

\begin{tabular}{ccccc}
\hline & & 介入前 & 介入後 & 差 \\
\hline 内旋群 & 安静時外旋角度 & $2.7 \pm 3.4$ & $4.9 \pm 5.0$ & $2.2 \pm 5.1$ \\
& 自動内旋角度 & $24.1 \pm 5.9$ & $36.0 \pm 7.0^{*}$ & $11.9 \pm 10.4$ \\
& 自動外旋角度 & $32.7 \pm 6.3$ & $33.7 \pm 9.4$ & $1.0 \pm 7.8$ \\
& & & \\
外旋群 & 安静時外旋角度 & $3.5 \pm 1.8$ & $4.8 \pm 4.1$ & $1.3 \pm 3.7$ \\
& 自動内旋角度 & $32.7 \pm 7.1$ & $36.3 \pm 8.3$ & $2.6 \pm 10.7$ \\
& 自動外旋角度 & $38.0 \pm 5.7$ & $36.8 \pm 9.2$ & $-1.2 \pm 7.8$ \\
\hline & & & (単位; 度, $\left.{ }^{*}: \mathrm{p}<0.05\right)$
\end{tabular}

\section{COP 軌跡}

いずれの項目においても介入前の群間差は認められ なかった。母趾 MP 関節レベルでは，交互作用は認 められたが， 2 群間および介入前後で有意差は認めら れなかった。母趾 MP 関節と舟状骨結節の中点レべ ルと舟状骨結節レベルでは, 交互作用が検出され,

Post-hoc 検定の結果, 介入後に下腿内旋エクササイズ 群は介入前と比べて中点レベルで $7.1 \%$, 舟状骨結節 レベルで $4.9 \%$ 内側に偏位し, 下腿外旋エクササイズ 群（中点レベル； $-5.9 \%$, 舟状骨結節レベル ; $4.2 \%$ ）と比較して有意に内側に偏位していた（中点 レベル； $p=0.008$ ，舟状骨結節レベル； $p=0.004 ） 。$ 踵部レベルでは交互作用は認められず，2 群間および 介入前後にも有意差は認められなかった（図 3 )。
内旋群

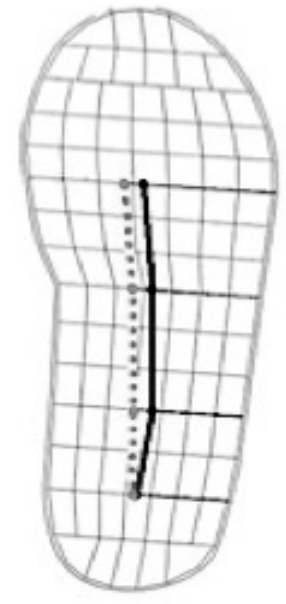

母趾MP関節

中点

舟状骨結節

踵部

介入前

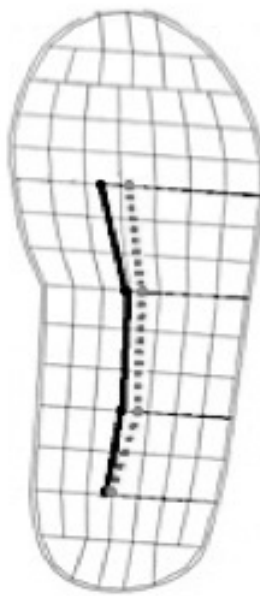

外旋群

\section{IV. 考 察}

本研究は, 下腿内旋位でのレッグプレス運動が, 若 年健常女性の歩行時足圧中心 (COP) 軌跡および下 腿回旋可動域に及ぼす効果を解明することを目的とし た。その結果, 介入前において下腿内旋エクササイズ 群の安静時回旋角度は外旋 $2.7 \pm 3.4^{\circ}$ であり, 下腿内 旋エクササイズによって下腿内旋可動域が増加し, さ らに歩行立脚後期における COP は下腿外旋エクササ イズ群と比較して内側へ偏位した。一方，下腿外旋工 クササイズ群では，下腿外旋可動域や COP に変化は 認められなかった。

本研究の対象者である健常女性の膝関節は, 介入前 に約 $3.1^{\circ}$ 下腿外旋位であった。先行研究において膝 OA のキネマティクスの特徵として下腿外旋傾向であ ることが報告された ${ }^{4,5)}$ 。我が国の膝 $\mathrm{OA}$ 有病率は女 性の方が多いと報告され ${ }^{1)}$, 健常女性における下腿回 旋アライメントの異常が膝 OA 発生のリスクファク ターの一つである可能性がある。一方，下腿内旋位で のレッグプレス運動を実施した結果, 内旋可動域が増 加し, 外旋可動域は増加しなかった。内旋位でのレッ グプレス運動の反復によって得られた自動内旋可動域 の増加は, 対象者が介入前に有していた他動可動域の 範囲内で起こった変化であると推測される。すなわち， 下腿内旋位レッグプレスによって自動内旋可動域が正 常範囲を超えて拡大したとは考えられず，介入前には 他動可動域と自動可動域に差があった状態が，介入に よって自動可動域が他動可動域に近づいたと解釈され る。このことは, 健常膝において自動下腿内旋運動の 減少が起こることを意味し,さらには膝関節のスク リューホーム運動や歩行などの動作習慣にも影響を及 ぼす可能性が示唆される。しかしながら，小規模・短 期間の無作為化研究である本研究において, この $3.1^{\circ}$ の下腿外旋が将来の膝 OA 発症とどのような関連性 を有するのかを議論することは出来ない。安静時下腿 外旋位掞よび内旋可動域制限が膝 OA 発症のリスク ファクターであることを実証するには，大規模なコ ホート研究が必要である。

膝 OA では, 歩行初期接地から立脚中期において COP が外側に偏位していだ)。一方，膝 OA を対象と した下腿内旋位レッグプレス運動は Q-angle の減少, すなわち膝伸展位での下腿外旋アライメントの改善を もたらした6)。また，健常女性を対象とした本研究に おいて，下腿内旋位レッグプレス運動は外旋位レッグ プレスと比較して歩行時 COP が内側偏位した。この 
結果は, 両群が共通に実施したレッグプレス中の股関 節運動の影響よりもむしろ, 下腿内旋エクササイズに よって生じた膝関節回旋アライメントの変化が立脚期 の後足部に扔ける内部回外モーメントの減少をもたら したためと考えられる。これらの結果から，下腿内旋 位レッグプレス運動は, 健常膝における COP の外側 偏位をある程度改善する可能性が示唆された。

本研究では下腿内旋エクササイズにリアライン・ レッグプレスを用いた。このため，全対象者が同一の 下腿内旋エクササイズを, 同一の負荷で行うことがで きた。また, この機器は持ち運び可能であり, 運動の 場所を選ばないことは， 2 週間という短期間の介入で あったとはいえ全対象者が指定した通りの介入を実施 した一因として挙げられる。測定に用いた簡易的下腿 回旋可動域測定装置の日間信頼性に関して, ICC $(1,5)$ およびSEM は0.62 $\left(0.71^{\circ}\right) \sim 0.86\left(1.22^{\circ}\right)$ であった。本研究結果では, 下腿内旋エクササイズ群 の介入前後の内旋可動域変化が $11.9^{\circ}$ であったことか ら, 簡易的下腿回旋可動域測定装置は本研究において 十分な信頼性を有していたと考えられる。よって、リ アライン・レッグプレスと簡易的下腿回旋可動域測定 装置を用いたことにより，測定結果と介入の再現性が 高められたものと思われる。一方, 本研究は若年健常 女性を対象にしたため, 男性や膝 OA 患者において も同様の結果が得られるかは不明である。本研究の限 界として, サンプルサイズの不足が挙げられ, 本研究 にて群間差が検出されなかった点について $\beta$ エラー が混入している可能性は否定できない。

本研究の結論を, 「下腿内旋位レッグプレス運動は, 健常な若年女性に打いて下腿内旋可動域改善と歩行中 の COP 内側偏位をもたらす可能性がある」とした。 下腿内旋位レッグプレス運動が膝 OA の予防㧍よび 進行防止の運動プログラムに応用できる可能性がある。 今後, 膝 $\mathrm{OA}$ 患者を対象とした更なる検証を進める 必要がある。

\section{文献}

1) Yoshimura N, Muraki S, Oka H, et al.: Prevalence of knee osteoarthritis, lumbar spondylosis, and osteoporosis in Japanese men and women: the research on osteoarthritis/ osteoporosis against disability study. J Bone Miner Metab, 2009, 27(5): 620-628.

2) Altman RD: Early management of osteoarthritis. Am J Manag Care, 2010, 16 Suppl Management: S 41-47.

3 ) Felson DT, Nevitt MC, Zhang Y, et al.: High prevalence of lateral knee osteoarthritis in Beijing Chinese compared with Framingham Caucasian subjects. Arthritis Rheum, 2002, 46(5): 1217-1222.

4) Hamai S, Moro-oka TA, Miura H, et al:: Knee kinematics in medial osteoarthritis during in vivo weight-bearing activities. J Orthop Res, 2009, 27(12): 1555-1561.

5 ) Saari T, Carlsson L, Karlsson J, et al.: Knee kinematics in medial arthrosis. Dynamic radiostereometry during active extension and weight-bearing. J Biomech, 2005, 38(2): 285292.

6 ) 吉田大佑, 蒲田和芳, 能由美 - 他 : 内側型変形性膝関節症 に対する下腿内旋エクササイズの即時効果. 日臨整誌, (印 刷中) :

7 ) Lidtke RH, Muehleman C, Kwasny M, et al.: Foot center of pressure and medial knee osteoarthritis. J Am Podiatr Med Assoc, 2010, 100(3): 178-184. 